\title{
Do taxes affect number of foreign enterprises controlled abroad by Slovak companies in the age of globalization?
}

\author{
Sona Kleštincová ${ }^{1, *}$ \\ ${ }^{1}$ University of Economics in Bratislava, Faculty of National Economy, Department of Finance, \\ Dolnozemská cesta 1, 85235 Bratislava, Slovakia
}

\begin{abstract}
.
Research background: Globalization has so far brought the possibility of international trade as well as the possibility of establishing companies abroad. Countries see a number of benefits in attracting foreign enterprises. However, the question arises about how countries may affect the number of enterprises established by domestic companies abroad?

Purpose of the article: The aim of this article is to find out whether corporate income tax rates have an impact on establishment of foreign controlled companies by Slovak companies abroad. Secondly, the aim of the work is to uncover whether trading across borders (which represents globalization), may influence the decision-making of such companies. To verify this, two groups of countries were created: one with a lower and the other with a higher average corporate income tax rates compared to the average rates in the Slovakia. The hypothesis is that paying taxes plays negative role in the number of foreign controlled enterprises by Slovak companies.

Methods: To estimate the hypothesis, the panel regression analysis is applied.

Findings \& Value added: The results of the work may help in policy making decisions aimed at monitoring of foreign controlled companies from the Slovak republic. The findings reveal that taxes might not be the best, and at the same time the results reveal different area that may affect the establishment of such companies - namely trading across borders.
\end{abstract}

Keywords: foreign controlled enterprises; corporate income tax rates; paying taxes, trading across borders, panel regression analysis

JEL Classification: F23; L26; H26

${ }^{*}$ Corresponding author: sona.klestincova@euba.sk 


\section{Introduction}

Previous research in the field of capital outflow have focused mainly on describing the determinants of the business environment that can be used by countries in the process of attracting FDI into the country $[1,2]$. Our research is based on the different point of view, which has not been examined much yet. This paper is focused on observation how and which determinants of the business environment in Slovak Republic affect domestic companies in the establishment of foreign affiliates. This approach has been chosen, because the FDI outflow, which is in some points quite similar to process of establishment of foreign affiliates (NoFA), is measured only in monetary units. That means, that FDI does not present the real amount of established and controlled affiliates abroad (and FDI include also many different types of investments, not only investments into the establishment of foreign affiliates). Approach based on the number of affiliates abroad, could extend recent knowledge in area of capital outflow. Benefits of this approach could be seen in more detailed view of FDI outflow, not only through the amount of money that has been taken out of the country, but it is possible to see, by how many companies are these investments used. Also, findings of this research reveal the determinants of business conditions, that affect local home companies in the process of establishing foreign controlled affiliates.

However, it is also necessary to keep in mind that Slovak companies can establish affiliates abroad for reasons other than changes in the business environment, for example because of specific natural resources. However, our research focuses on the impact of the business environment and therefore we put aside other reasons for establishing foreign affiliates.

\subsection{Literature review}

In the field of FDI plethora of researches has been done. Some of them focus on the influence of FDI on country economy [3], another has been searching for determinants of FDI inflow or outflow. [4] The nature of this article is very similar to these researches, which has been trying to name the determinants of FDI outflow. The FDI outflow, which is for purposes of this work replaced by number of foreign controlled affiliates (NoFA), can be perceived as something negative. However, some researchers proved, that FDI outflow does not have to be perceived as negative for home country. [5] Actually, FDI outflow, should have positive or, in some few cases, none of impact on employment in country of FDI origin. [6, 5] Purpose of this article is to find out whether there are some significant determinants affecting establishing affiliates abroad, and in the case that there are some of them, it could create a place for further research, which can prove or disapprove the statements of previously mentioned researches.

Company decision-making about establishment of an affiliate abroad or the placement of FDI abroad could be based on effort to obtain the privileged tax regime in host country. $[7,8]$ On the other side, there are also findings, that prove existence of different determinants, than taxes. $[9,10]$ As the example it is possible to name some of them: openness of economy, development of intentional trade, natural resources of county, hostcountry financial development [11], size of the domestic market, language barriers and so on [12]. Research focused on EU countries has find out, that there can by differences in the determinants affecting FDI, according to different regions. [13] In our research we focus on the determinants actuating in home country, which affect local companies to establish affiliate abroad. This approach is used in just few of researches. Some of determinants that has been found as significant for FDI outflow are policies in home country related to foreign trade, financial sector and investment development. [14] Companies can use FDI 
outflow also for enhancing their competitiveness. [15] All of these mentioned areas are the building stones of business environment, that surrounds the companies.

To capture the nature of the business environment, we chose the Doing business (DBI) indicators. In various researches, the authors have already used the DBI index and its individual indicators $[1,2]$, but mainly in connection with the inflow and outflow of FDI [16]. On the contrary, this research is focused on the influence of indicators on the number of established foreign affiliates controlled by Slovak companies. Some authors warn from using DBI indexes in connection with multinational or international operating companies, as the DBI index is only calculated on the data obtained from home companies. However, this opinion has no longer been true, DBI indexes capture an image of business surrounding, weather it is home or multinational foreign company. [17] In his article the perspective is set on Slovak businesses establishing affiliates abroad, so the usage of DBI index should not face the same problem as mentioned.

\section{Methods and Data}

\subsection{Data}

Dependent variable NoFA represents total number of foreign affiliates controlled by ultimate institutional controlling unit which is located in Slovakia. Data for depended variable has been collected form Eurostat database [fats_g1a_08]. The NoFA variable in this research replaces variable FDI outflow, that has been commonly used in previous papers.

Independent variables are represented by selected DBI indicators. There exist total 10 DBI indicators. The following one were used in this paper: Paying taxes $(P T)$; Trading across borders $(T a B)$; Enforcing contracts $(E C)$; Resolving Insolvency $(R C)$. The remaining variables were removed, due to non or very low degree of variance in the observed period 2008-2014.

Table 1. Summary statistics for independent variables DBI (2008-2014).

\begin{tabular}{|c|c|c|c|c|}
\hline $\begin{array}{c}\text { Independent variable } \\
\text { represented by DBI subindex }\end{array}$ & Mean & $\begin{array}{c}\text { Standard } \\
\text { deviation }\end{array}$ & Min & Max \\
\hline Starting a business & 70.72 & 0.5540758 & 69.9 & 71.4 \\
\hline Dealing with Construction Permits & 61.31 & 0.3670993 & 60.5 & 61.5 \\
\hline Getting Electricity & 77.36 & 0.1140175 & 77.2 & 77.5 \\
\hline Registering Property & 91.89 & 0.0377964 & 91.8 & 91.9 \\
\hline Getting Credit & 75 & 0 & 75 & 75 \\
\hline Protecting Minority Investors & 46.7 & 0 & 46.7 & 46.7 \\
\hline Paying Taxes & 63.97 & 4.610753 & 59.4 & 70.4 \\
\hline Trading across Borders & 75.23 & 1.452256 & 72.7 & 76.6 \\
\hline Enforcing Contracts & 64.24 & 1.05017 & 62.5 & 65.5 \\
\hline Resolving Insolvency & 67.86 & 2.50257 & 65 & 70.4 \\
\hline
\end{tabular}


The selection of data sources (Eurostat, DBI) of both independent and dependent variables is justified by the fact that methodology of their calculation is identical in all monitored countries and throughout the observed period. However, we are aware also of their weaknesses, specifically in the case of independent variables (DBI indicators). The evaluation of its values may show signs of subjectivity. The volume of subjectivity is limited due to high amount of companies filling the questionnaire, according which the DBI indexes are calculated

Data in this paper are collected from 2008 to 2014. This period is selected because it does not contain breaks in the methodology of variable calculations. The data of dependent variable include the number of controlled foreign affiliates in EU countries by Slovak residents except Cyprus, Luxemburg, Spain, France, Belgium, Greece. These countries were excluded because of data issue : there are missing data for 2 or mostly more than 2 years, and in addition these data has almost no variance with zero values.

\subsection{Methodology}

To estimate the determinants coefficients of business environment in relation to the number of established foreign affiliates by Slovak companies, the panel data regression has been used. We choose this method due to the nature of the data, which consist of space dimension (represented by countries, in which the controlled affiliates are located) and the dimension of time (observed period 2008-2014). To choose between random and fixed effects in panel data regression results, we used Hausman test. According to the results of this test, the random effects has been chosen.

According to findings of previous researches mentioned in literature review, evidences about tax reasons driven decisions of companies about establishing foreign controlled affiliate do exist $[7,8]$. That is why we split the database of countries into two groups, this approach is inspired by researches, where authors use two or more groups of countries and compare the differences among them. [18] To create these two groups of countries, we have calculated average CIT rate, from the nominal values of CIT rates used in selected countries, in observed period of time from 2008 to 2014. After that we have calculated the average CIT rate in the same time period for Slovakia. After that we have divided all of the countries into two groups. First group consists of countries with lower average CIT rate, than the average CIT rate for Slovakia, and the second group consist of countries with higher average CIT rate in observed period of time, than average CIT rate in Slovakia.

\subsection{Developing Hypothesis}

Estimated equation:

$$
N o F A=\beta+\beta \cdot P T+\beta \cdot T a B+\beta \cdot E C+\beta \cdot R I
$$

H1: According to previous research we assume, that in countries with lower average CIT, independent variable Paying taxes $(P T)$ is going to be significant and with negative value.

Explanation of this assumption is that, if Slovak business environment gets better evaluation (that could be achieved by lowering tax liability or by reducing time to fill tax declaration), then the companies should no longer need to shift their profit or "escape" to the jurisdictions with better business conditions. If companies in Slovakia do not establish foreign affiliates abroad because of the lower rate of CIT, the coefficient estimated in panel data regression should not be significant and hypothesis $\mathrm{H} 1$ would be rejected. 
H2: Globalization represented by Trading across borders $(\mathrm{TaB})$ sub index of DBI, should have significant impact on number of foreign affiliates under control of Slovak companies in both groups of countries.

This assumption is developed according to findings in research focused on FDI. [16] Also in our research we assume the similar findings. According to estimated sign of this determinant, we assume negative sign in both groups of countries. Globalization brings to these days possibility of fast and cheaper transport of goods. So if he trading across borders is going to be easier, companies would not have to had so many establishments in foreign countries. As the costs of transport are getting lower the costs of establishing and maintaining foreign affiliate could be perceived by companies higher than transport costs.

\section{Results and Discussion}

This article aims to estimate the influence of the different business conditions or in other words business environment determinants and regulations that affect controlling companies in establishing foreign affiliates. Among the areas of corporate regulation, we have monitored 4 DBI sub indexes in our work. Results of the panel data regressions for both groups of countries are presented in the following table.

Table 2. Estimated coefficients with their standard deviation value - panel data regression done in case of countries with lower and higher average CIT than average CIT of Slovakia during the period 2008-2014.

\begin{tabular}{|c|c|c|}
$\begin{array}{c}\text { NoFA (Number of } \\
\text { foreign affiliates) }\end{array}$ & $\begin{array}{c}\text { Countries with } \\
\text { lower average CIT } \\
\text { than CIT in } \\
\text { Slovakia }^{1}\end{array}$ & $\begin{array}{c}\text { Countries with } \\
\text { higher average } \\
\text { CIT than CIT in } \\
\text { Slovakia }^{\mathbf{2}}\end{array}$ \\
\hline \multirow{2}{*}{$\boldsymbol{P T}$} & 4.396341 & 3.265208 \\
$(0.429)$ & $(0.166)$ \\
\hline \multirow{2}{*}{$\boldsymbol{T a B}$} & $\mathbf{- 5 2 . 6 3 8 9 3}$ & .1333316 \\
& $\mathbf{( 0 . 0 0 9 ) * *}$ & $(0.986)$ \\
\hline \multirow{2}{*}{$\boldsymbol{C} \boldsymbol{T}$} & -9.561894 & -.8567941 \\
\multirow{2}{*}{$\boldsymbol{R I}$} & $(0.686)$ & $(0.931)$ \\
\hline \multirow{2}{*}{ constant } & 14.37451 & 2.783019 \\
& $(0.239)$ & $(0.576)$ \\
\hline & 3467.611 & -295.5575 \\
$(0.101)$ & $(0.739)$ \\
\hline
\end{tabular}

Legend:

$* \mathrm{p}<.05 ; * * \mathrm{p}<.01 ; * * * \mathrm{p}<.001$

1 list of countries: Croatia, Bulgaria, Romania, Latvia, Slovenia, Lithuania, Estonia, Poland, Czech Republic

${ }^{2}$ list of countries: Norway, Finland, Denmark, Sweden, Hungary, Netherlands, Germany, Portugal, Austria, Italy, Malta, Ireland

$$
\begin{aligned}
\text { NoFAlow CIT }= & 3467.611+4.396341 \cdot P T-52.63893 \cdot T a B-9.561894 \cdot E C \\
& +14.37451 \cdot R I \\
\text { NoFAhigh CIT }= & -295.5575+3.265208 \cdot P T+0.1333316 \cdot T a B-0.856794 \\
& \cdot E C+2.783019 \cdot R I
\end{aligned}
$$

Results in the table show, that according to our primary assumptions, based on literature review, paying taxes did not prove estimation of significant results in either of two group. 
Hypothesis $\mathrm{H} 1$ assumed that for countries with a lower average CIT, the coefficient for the $P T$ variable would be significant and negative. Based on the results we reject $\mathrm{H} 1$ hypothesis. This result may be caused by the fact that the data of variable $P T$ includes evaluation of subjects only in two areas. The first area includes tax to profit ratio and the second is measuring the time needed to calculate and pay the tax. However, the problem, that can distort not only these results but also other researches in the field of international taxation are, for example, tax evasion or various other forms of tax relief, which are very difficult to capture and measure, as these concessions from government may vary across countries.

The second hypothesis assumed a significant influence of $T a B$ on the number of established controlled affiliates abroad. We accept this hypothesis in the case of a group of countries with a lower CIT than the average CIT in Slovakia. In the case of the second group of countries, we reject hypothesis H2. In the first group of countries, estimated coefficient that belongs to $T a B$ variable has negative sign. This can be explained by the fact, that if trading across borders gets better evaluation in DBI, companies do not have to establish foreign affiliate. However, they can move their products and goods across borders faster and with lower costs. At that point establishing foreign affiliate could be less effective.

The rest of the variables do not have significant impact on Slovak companies establishing foreign affiliates. In the both groups of the countries, value of the R-squared has a lower values (R-sq low CIT: within R-sq $=0.1327$; between $\mathrm{R}$-sq $=0.0324$; overall $\mathrm{R}$-sq $=0.0170)$, $(\mathrm{R}$-sq high CIT: within $=0.1196$; between $=0.0149$; overall $=0.0179)$. The lower value of R-sq can be explained by the nature of the data used in panel data regression. The data consist of the observed time series and also of the data for each country in the group. Value of the R-sq can be lowered by the fact, that there has been used data for different countries across the time, and this could be the reason why R-sq has lower than expected values. Also, there may be many different variables, that can affect the number of foreign affiliates, that has not been included in the model. And thirdly, all of the models, that contains data affected by human decisions (decision whether to establish foreign affiliate or not, can be affected by subjectivity) are known for very low R-sq values.

From these findings it is possible to see that openness of the borders, low transportation costs and reducing time that needs to be taken to check transported goods can help to keep companies activity in Slovakia. These findings open new space for further research. This research could focus on the, impact of openness of the economy and globalization to employment, and production in Slovakia.

\section{Conclusions}

Business environment is still evolving and changing. One of its parts is created also by laws and regulations of businesses. Many of researches have been done in the field of FDI inflow and outflow and its connection to different areas of business regulations. This paper extends already existing literature, by monitoring the relationship between amount of established foreign affiliates controlled by Slovak companies and the changes in four selected business regulations areas.

Most interesting findings reveal that the more open country is and more easy transport of goods is, the less foreign controlled affiliates Slovak residents establish abroad. This finding reveals possibility of further research, which could find out whether this behavior of companies leads to rise of employment and production in Slovakia.

On the other hand, results of panel data analysis did not confirm the previous results of past researches, in which paying taxes played a significant role in decision making of companies establishing foreign affiliates. One of the possible explanations to this results 
can be find in the nature of used data. Indicator paying taxes in DBI, does not count with tax holidays or other individual tax reliefs used by governments of some countries to attract foreign investors.

It is important for policy makers to see the both, inward and outward, ways of the foreign affiliates establishment. Many countries try to find the ways how to attract foreign enterprises, and forget about the local ones, which due to unfriendly business environment for them, maybe have to establish their foreign affiliates abroad and by these steps take some part of production and employment away from their home country. Or the establishment of foreign affiliate could lead to rise in the employment and production of the home country. This point of view could be the possible way to extend findings of this research in future.

The paper is an output of the scientific project VEGA No 1/0779/19 Challenges of digitization of the economy in the field of taxation, possible solutions and their assumptions.

\section{References}

1. Contractor, F. J., Dangol, R., Nuruzzaman, N., Raghunath, S. (2020). How do country regulations and business environment impact foreign direct investment (FDI) inflows? International Business Review, 29(2), 101640.

2. Vučković, M., Bobek, V., Maček, A., Skoko, H., Horvat, T. (2020). Business environment and foreign direct investments: the case of selected European emerging economies. Economic Research-Ekonomska Istraživanja, 33(1), 243-266.

3. Zhang, K. H. (2001). How does foreign direct investment affect economic growth in China? Economics of transition, 9(3), 679-693.

4. Maiti, D., Mukherjee, A. (2013). Governance, foreign direct investment and domestic welfare. International Review of Economics \& Finance, 27, 406-415.

5. Hijzen, A., Jean, S., Mayer, T. (2011). The effects at home of initiating production abroad: evidence from matched French firms. Review of World Economics, 147(3), 457.

6. Doskaliyev, I. (2015). The impact of FDI outflows on the unemployment rate in the source countries., Economic and Social Development. In A. Vuletic, R. Danijela Vlahov, I. Pihir (Eds.) Proceedings of the 11th International Scientific Conference on Economic and Social Development - Building Resilient Society (pp. 312-320). Varazdin: Varazdin Development and Entrepreneurship Agency (VADEA).

7. Li, X., Tran, A. (2019). An empirical study on cross-border profit shifting in Australia. Ejournal of tax research, 17(2), 193-232.

8. Janský, P., Palanský, M. (2019). Estimating the scale of profit shifting and tax revenue losses related to foreign direct investment. International Tax and Public Finance, 26(5), 1048-1103.

8. Wyrwa, J. (2019). Analysis of determinants of the inflow of foreign direct investment to Poland. Part I-theoretical considerations. Management - Poland, 23(2), 238-262.

9. Wyrwa, J. (2020). Analysis of determinants of the inflow of foreign direct investment to Poland. Part II-research results. Management - Poland, 24(1), 157-175.

10. Bilir, L. K., Chor, D., Manova, K. (2019). Host-country financial development and multinational activity. European Economic Review, 115, 192-220.

11. Aleksandruk, P., Forte, R. (2016). Location determinants of Portuguese FDI in Poland. Baltic Journal of European Studies, 6(2), 160-183. 
12. Artige, L., Nicolini, R. (2006). Evidence on the determinants of foreign direct investment: The case of three European regions. Unitat de Fonaments de l'Anàlisi Econòmica (UAB) and Institut d'Anàlisi Econòmica (CSIC): CREPP Working Papers.

13. Nayyar, R., Mukherjee, J. (2020). Home country impact on Outward FDI from India. Journal of Policy Modeling, 42(2), 385-400.

14. Amin, A., Anwar, S., Liu, X. H. (2020) Outward foreign direct investment and economic growth in Romania: Evidence from non- linear ARDL approach. International Journal of Finance \& Economics, 2020, 1-13.

15. Jovanovic, B., Jovanovic, B. (2018). Ease of doing business and FDI in the exsocialist countries. International Economics and Economic Policy, 15(3), 587-627.

16. Jayasuriya, D. (2011). Improvements in the World Bank's ease of doing business rankings: do they translate into greater foreign direct investment inflows? The World Bank Policy Research Working Paper, No. 5787.

17. Kubicová, J. (2013). The Role of Corporate Income Tax in Foreign Direct Investment Inflows into the "Old" and "New" EU Member States. Research Project VEGA, 1(0238), 13. 